\title{
The Study on Innovation-driven Factors and Growth Path of Constructing Innovative City of Tianjin
}

\author{
Yan-Hua ZHAO ${ }^{1, a}$ Jie ZHANG $^{2, b,{ }^{*}}$ \\ ${ }^{1}$ Department of Management Science and Engineering, Tianjin University of Finance and Economics, \\ Tianjin, China \\ ${ }^{2}$ Department of Management Science and Engineering, Tianjin University of Finance and Economics, \\ Tianjin, China

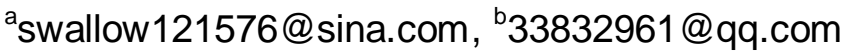 \\ ${ }^{*}$ Corresponding author
}

Keywords: Innovative city, Innovation-driven factors, Growth path, System dynamics.

\begin{abstract}
The construction of innovative city is a dynamic innovative system. The internal elements of the system have the characteristics of divergent, nonlinear, delay. It's difficult to analyze with one-sided cognition and experience. The thesis is based on the analysis of the city's driving factors, combined with the theory and approach of system dynamics, conducted a profound study of whole and local innovation system of Tianjin, understood the mechanism of each factor, and given suggestions to the construction of innovative city of Tianjin .
\end{abstract}

\section{The analysis of innovation-driven factors for Tianjin}

\section{The innovation-driven factors of constructing innovative city}

The construction of innovative city is complicated system engineering. Ultimately, it is formed by the mutual impact of the innovative factors. The construction of the innovative city is divided into the subject driving factors, internal resource driving factors, and external environment driving factors. Three types of driving elements contributed to the system of innovative city.

1. The subject driving factors

The subject driving factors of innovation city include enterprise, government, research institutions, financial institutions, intermediary agency. Among these, enterprises' responsibility is using new technologies and new manners in the production and realizing marketization, so it is the most interior driving force in system. Government provides necessary basic installation for each creative organization and the main part of creation, and provides capital by public finance, safeguard by law, and creates the necessary condition for creative resource playing its utmost role. The research institutions including different kinds of research academies in city, possess the ultramodern technology and innovative talents, and provide necessary scientific theory and various kinds of patented invention for innovation system. Financial institutions to provide necessary funds for the city innovation systems, analysis the risk of the project, then choose and support it, guide research projects to establish relationship with market. Intermediary agencies strengthen the connection between each different subsystem, accelerate the spread of knowledge and circulation of technology, thus achieving operational coordination between the various sub-subjects.

2. Internal resource driving factors

City resources include natural resource, cultural resource, human resource, economic resource and political resource. Natural resources include city's natural endowment, urban infrastructure conditions, urban environment, urban conditions and so on. Cultural resources include city's cultural accumulation, historical contest, cultural features. Human resources include the scientific researchers' amount, structure, level etc. Economic resources include city's economic power, industrial structure, industrial cluster. And policy resources include the city's positioning, policy advantages, system of safeguards. Kinds of resources' liquidity and integration realize the support to city's development and innovation. 


\section{External environment driving factors}

City innovation system is an open system, its process and direction will be affected by exterior conditions. Exterior conditions driving factors include macro-economics, policy, market, regional environment and casual factors. Macro-economic provides innovative activities for the cumulative effect of the city, and promotes and guides the innovative activities. Macro-policy promotes the industrial transformation from its benefits and incentive systems in different industries. The needs of market promote the beginning of innovate activities and the integrated of the enterprise. Regional environment provide a platform which the inner and outer factors could exchange, and regional coordination facilitate the factors of different cities to flow and complement. In addition, something or some activities could drive city innovation, were called as casual factors.

\section{The mechanism of interaction of three factors}

Synergistic effect of three driving factors contributed to the continuous innovation of the city, driving mechanism is shown in Fig.1.

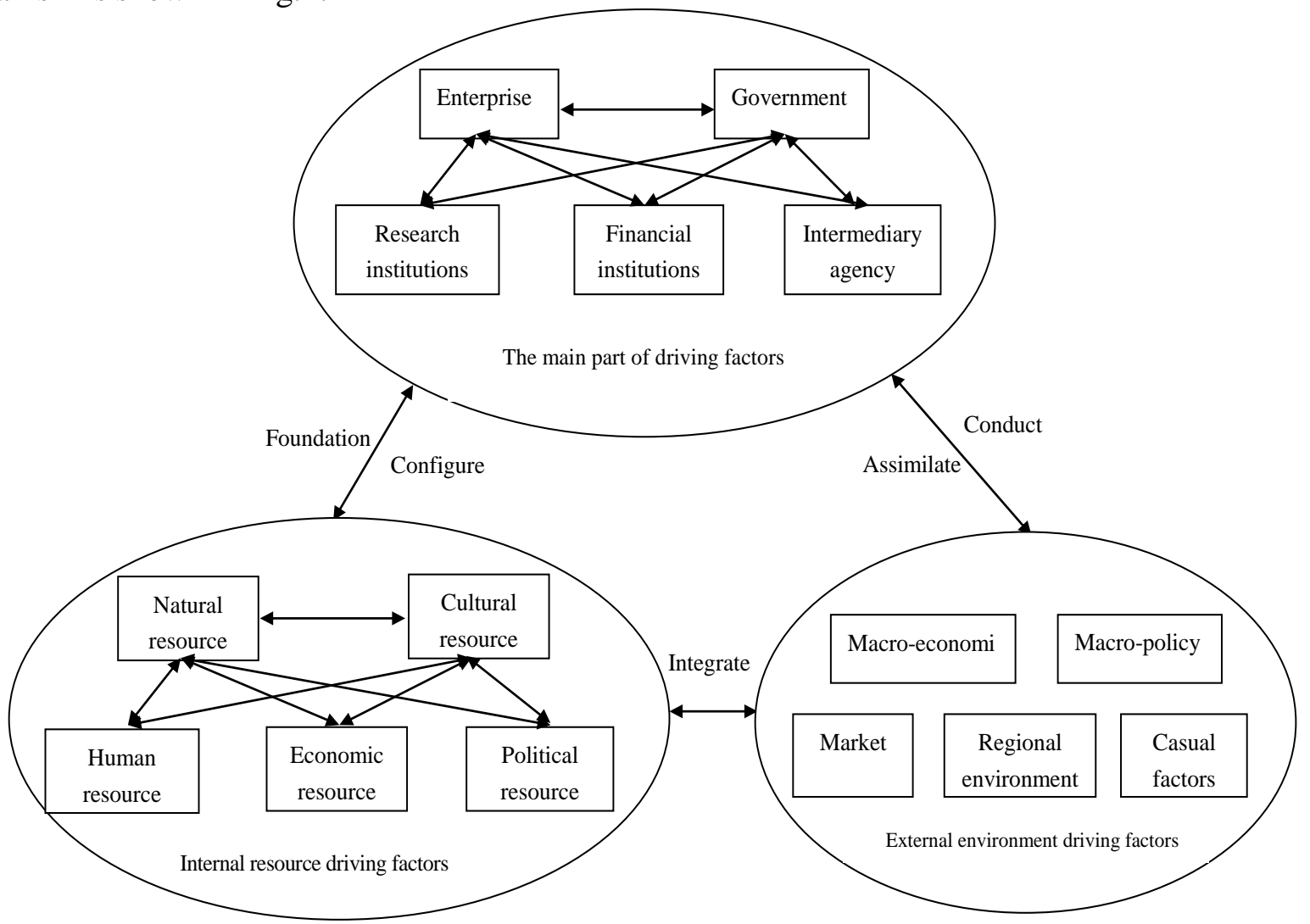

Fig.1 Driving factors of the constructing innovative city

City resources system provides the foundation and the support for the city innovation, the breakthrough of city innovation industrial must be integrated with the city's own resource condition, and the characteristic resources can drive the whole city innovation breakthrough. The subject driving factors of city innovation realize innovation activities continuous development according to the rational allocation of city resources. Five main elements have power integration through various activities such as research development, investment, service. Combining with the system inside and outside of the overall situation, under the guidance of policy and market, taking enterprises as the core, through the enterprise independent research and development, or obtain and adopt new technology from other social institutions, using new technology, bringing in new management methods, owning new resource, producing new products, providing new services, opening up new markets, ultimately to enhance the city's ability to innovate and improve the whole level of innovation system. The main body of city innovation in the process of innovation constantly absorbs foreign advantage factors of production, at the same time; external environmental factors influence the direction of city innovation through the information transmission of the innovation subject and with the integration of internal resources factors. 


\section{The analysis of growth path of constructing innovative city of Tianjin}

\section{Selection of indicators}

The basic elements of city innovative consist of innovative capital, innovative resources personal, innovative resources and productions as well as innovative technology. The innovative capital is mainly considered from its input structure (the source structure of innovative capital), which contains science and technology input from the government ,the research and development input from each firm, universities and scientific research institutions etc. Innovators regard the scientific and technological staffs as the research subjects, including enterprises and universities and research institutions. The innovative resources and productions are mainly accounted about economic and social benefits, mainly refers to the innovative technology that is patent output and accept values of new product .

Evaluation factors of city innovation system running effect mainly should be from two aspects, as the economic effects and social effects. First of all, the economic effects of the city innovation system should be considered, it refers an innovative city system's contribution to the urban economy ,and the effect of input and output indicators, just as the sales of new product. At the same time, we should also consider the social effect of city innovation system, the quantity of patent applications are selected as the evaluation index, it reflects technology innovation ability of the city innovation system, the performance of the level of science and technology, and illustrates the development potential of an area.

\section{Construction of city innovation system's causality diagram}

In this paper,based on system dynamics method which is suitable for the study of complex social and economic relationship, on the basis of feedback control theory,by means of computer simulation technology, considered the behavior of innovation subject and interaction as the main line,we began to establish causality diagram of city innovation system, as shown in Fig.2.

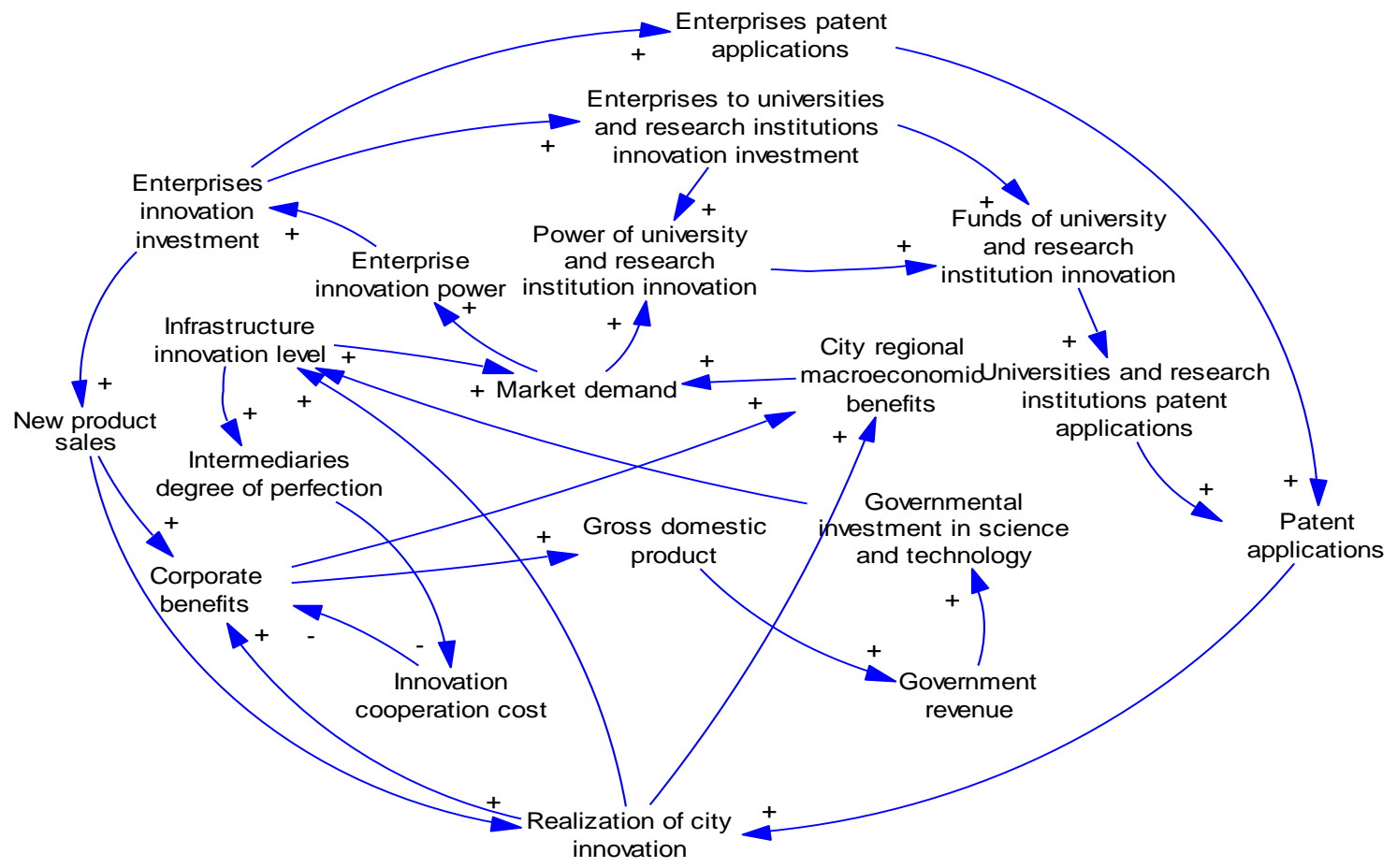

Fig.2 Causality diagram of city innovation system

Therefore, the structure of the system causal relationship has the following seven main feedback loop:

1. Market demand-Enterprise innovation power-Enterprises innovation investment Enterprises patent applications_—Patent applications (New product sales) — Realization of city innovation_C City regional macroeconomic benefits.

2. Market demand — The power of university and research institution innovation — The funds of university and research institution innovation_-Universities and research institutions patent 
applications_-Patent applications_-Realization of city innovation —City regional macroeconomic benefits.

3. Market demand_-Enterprise innovation power_—Enterprises innovation investment-New product sales - Corporate benefits_-Gross domestic product-Government revenue_-Governmental investment in science and technology_-Infrastructure innovation level.

4. Market demand-Enterprise innovation power-Enterprises innovation investment_-Enterprises to universities and research institutions innovation investment—The power of university and research institution innovation- The funds of university and research institution innovation_-Universities and research institutions patent applications —-Patent applications_— Realization of city innovation_—City regional macroeconomic benefits.

5. Market demand_-Enterprise innovation power_—Enterprises innovation investment_— New product sales_—Realization of city innovation_—-Infrastructure innovation level_ — Intermediaries degree of perfection-Innovation cooperation cost-Corporate benefits-City regional macroeconomic benefits.

6. Enterprise innovation power_—Enterprises innovation investment_-Enterprises to universities and research institutions innovation investment— The funds of university and research institution innovation-Universities and research institutions patent applications_-Patent applications_- Realization of city innovation_ Corporate benefits.

7. Enterprise innovation power-Enterprises innovation investment_-Enterprises patent applications_-Patent applications _ Realization of city innovation - Infrastructure innovation level__ Intermediaries degree of perfection__ Innovation cooperation cost_—Corporate benefits.

These feedback loops combine the various elements of the system together, and thus generate a role to the whole city innovation system. These loops contact the elements of the innovation system together, can be considered as mechanism or path.

\section{Suggestions to the construction of innovative Tianjin}

From the causality diagram of city innovation system can be seen that the realization of city innovation, received the role of two factors, one is the new product sales, another is the patent applications. The former mainly reflects enterprise's perspective, while the latter mainly reflects the effect of university-industry-research cooperation. Also learned, most enterprises in city innovation system make relevant decisions and actions according to the market and the profit. At the same time, the effect of university-industry-research cooperation, on the one hand, determined by the degree of the combination of enterprises, colleges, research institutes, on the other hand, also under the influence of innovation infrastructure level and investment.

Tianjin is in the key period of constructing innovative city. Facing the challenge and opportunity exist at the same time, the author puts forward the following suggestions. First of all, play the main driving factors of core function. Playing a leading role of enterprises in the integration of innovation resources, strengthening the dominant position of the enterprises in the university-industry-research cooperation, and encourage scientific research institutions, intermediary agencies for enterprises to promote scientific and technological achievements. Secondly, strengthen the supporting to the internal resources. Talent, to the capital-talent as the core, to the global formation as the focus, vigorously the introduction of high-level talents of innovation of international and domestic, with Tianjin industrial upgrading of the city development and the industrial structure needs, developing various occupation education, cultivating a large number of occupation skill talents. Scientific and technological capacity, we should integrate the resources of science and technology, form the science and technology innovation together, establish the science and technology service system. Industry structure, we should develop the supported industry, cultivate strategic emerging industry and industry of new and high technology, speed up the transformation and upgrading of traditional industries, promote the optimization of industrial structure, to achieve the goal of the advantages of industrial cluster development, and achieve the goal of the industrial structure to high transition. Finally, enhance the promotion of the external environment, perfect the policy system of city innovation, and strive to transform the functions of government, speed up the cultivation of innovation mechanism and innovation service system, widely absorbing domestic and foreign innovation 
resources, construction of the "Beijing Tianjin Science and technology Shinkansen" regional economic cooperation in science and technology, establish ring interaction mechanism of Bohai, promote innovation synergy between regions, construct the open city innovation development pattern.

\section{Acknowledgement}

This research was financially supported by the Science and Technology Development Strategy research of Tianjin, No: 12ZLZLZF03000.

\section{References}

[1] David Doloreux. Saeed Parto. Regional innovation systems: current discourse and unresolved issues [J].Technology in Society. 2005.27.

[2] James Simmie. Innovative Cities [M]. London: Spon Press, 2001.

[3] Charles Landry. The Creative City: A Toolkit for Urban Innovators [M]. London: Earthscan Ltd,2000.

[4]Deci Zou. Analysis of the factors to build innovative city [J]. Science and Technology Industry of China. 2005(10):13-15.

[5]Fan Ye. Realization of path and construction elements of innovative city [J]. Guilin municipal party school journal. 2006.6(2):48-51.

[6]Ming Dai, Pengxiao Zhang. Analysis of the path and latent factors of innovative city and innovative enterprise development [J]. Science and science management. 2011(1):60-66.

[7]Zhihe Zhang, Hua Ding, Lijie Sun. Innovative city and the industrial innovation system [J]. Science and science management.2006. 7(12):150-155. 